\title{
Views of algology inpatients about ethical issues related to pain
}

\author{
Algoloji kliniğinde yatan hastaların ağrı ile ilgili etik konulardaki görüşleri
}

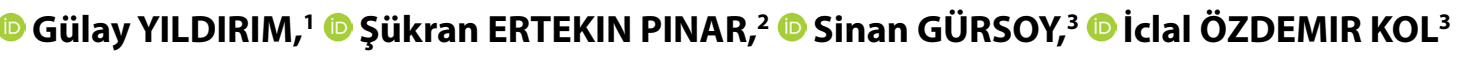

\begin{abstract}
Summary
Objectives: To determine the views of patients hospitalized in the algology clinic about ethical issues related to pain. Methods: A total of 135 patients admitted to the algology clinic comprised the population of this descriptive study. Data were collected using the visual analogue scale (VAS) and the questionnaire on ethical issues related to pain. To evaluate the data, percentage distribution and the Tukey test of variance were used.

Results: Of the patients, $92.6 \%$ believed that they had the right to pain relief, and $94.8 \%$ believed that they should be consulted when decisions about them were made. It was determined that $43.0 \%$ of the patients disagreed with Proposition 1 , "When a terminal-stage cancer patient with unrelievable pain requests an overdose of pain medication, possibly to cause death, the physician must prescribe it," while $51.9 \%$ of the participants disagreed with Proposition 2, "When a terminal-stage cancer patient with unrelievable pain and his or her family request an overdose of pain medication, possibly to cause death, the physician must prescribe it," and $44.4 \%$ of them disagreed with Proposition 3, "When a terminal-stage cancer patient with unrelievable pain requests an overdose of pain medication, possibly to cause death even though his or her family refuses, the physician must prescribe it." A statistically significant relationship $(p<0.05)$ was found between the mean VAS scores and Propositions 1 and 3.
\end{abstract}

Conclusion: The patients were willing to be informed and to be asked about their views regarding the issue, but they did not want to be prescribed a high dose of pain medication, possibly to cause overdose and death.

Keywords: Ethics; ethical dilemma; patients with pain; views about ethics.

\section{Özet}

Amaç: Algoloji kliniğinde yatan hastaların ağrıyla ilgili etik konulardaki görüşlerini belirlemektir.

Gereç ve Yöntem: Tanımlayıcı çalışmanın örneklemini algoloji kliniğindeki 135 hasta oluşturmuştur. Veriler Visüel Analog Skala (VAS) ve ağrıyla ilgili etik konuları kapsayan soru formuyla toplandı. Verilerin değerlendirilmesinde yüzdelik dağılım, Tukey testi ve Varyans analizi kullanıldı.

Bulgular: Hastaların \%92.6'sı ağılarının giderilmesi hakkı olduğuna, \%94.8'i kendileriyle ilgili karar alınırken görüşlerinin alınması gerektiğine inanmaktadırlar. “ileri dönem kanseri olan bir hastanın dindirilmesi mümkün olmayan şiddetli ağrısı için ölümüne neden olabilecek miktarda ağıı kesici ilaç istediğinde doktor aşırı doz ilacı vermelidir"önermesine hastaların \%43.0'ünün katılmadığı belirlendi. Aynı durumda iken ölümüne neden olabilecek miktarda ağı kesici ilacı, aile-hasta istediğinde doktorun aşırı doz ilacı vermesi gerektiğine katılımcıların \%51.9'unun, aile istemeyip, hasta istediğinde doktorun aşırı doz ilacı vermesi gerekliliğine ise \%44.4'ünün katılmadığı saptandı. VAS puan ortalamaları ile ileri dönem kanseri olan bir hastanın dindirilmesi mümkün olmayan şiddetli ağrısı için ölümüne neden olabilecek miktarda ağrı kesici ilacı hastanın kendisi istediğinde veya ilacı aile istemeyip hasta istediğinde doktor aşırı doz ilacı vermesi gerektiği ile ilgili önermeler arasında istatistiksel olarak anlamlı fark olduğu bulundu $(\mathrm{p}<0.05)$.

Sonuç: Hastalar konuyla ilgili bilgilendirme yapılmasını, görüşlerinin sorulmasını isterken ölümüne neden olacak aşırı doz ilacın verilmesini istememektedirler.

Anahtar sözcükler: Ağrısı olan hasta; etik; etik ikilem; etik ile ilgili görüşler.

The study was presented in the form of an oral presentation in 8. International Participation Congress of Turkish Bioethics Society (09-12 April 2015, Ankara/Turkey).

'Department of History of Medicine and Ethics, Cumhuriyet University Faculty of Medicine, Sivas, Turkey ${ }^{2}$ Department of Midwifery, Cumhuriyet University Faculty of Health Sciences, Sivas, Turkey

${ }^{3}$ Department of Anesthesiology and Reanimation, Cumhuriyet University Faculty of Medicine, Sivas, Turkey

Submitted (Başvuru tarihi) 01.10.2018 Accepted after revision (Düzeltme sonrası kabul tarihi) 12.03.2019 Available online date (Online yayımlanma tarihi) 09.07.2019

Correspondence: Dr. Gülay Yıldırım. Cumhuriyet Üniversitesi, Tıp Fakültesi, Tıp Tarihi ve Etik Anabilim Dalı, Sivas, Turkey.

Phone: +90 - 505 - 4761149 e-mail: gyildirimg@gmail.com

(C) 2019 Turkish Society of Algology 


\section{Introduction}

The International Association for the Study of Pain (IASP) describes pain as an unpleasant sensory and emotional experience associated with actual or potential tissue damage, or described in terms of such damage. ${ }^{[1]}$ Pain adversely affects a person's wellbeing, functional capacity and quality of life by affecting his/her productivity, relationships, self-care, and physical, social and mental functions. ${ }^{[2]}$ The prevalence of chronic pain in hospitalized patients is reported to range between $25 \%$ and $40 \% .^{[3]}$ In the literature, $33 \%$ of family members reported that their loved one had moderate to severe pain in early 1997. However, in late 1997 , the rate was $57 \%{ }^{[4]}$ In the literature, chronic pain prevalence is reported to vary between $2 \%$ and $54 \%{ }^{[5]}$ In a study conducted in 15 European countries, of the respondents, $66 \%$ had moderate pain, $34 \%$ had severe pain and $46 \%$ had constant pain. ${ }^{[6]}$ Since the perception and definition of pain, and responses to pain change from one person to another, ${ }^{[1,7,8]}$ the patient's statement regarding pain should be taken into account. ${ }^{[2,7]}$ In the literature, nurses' assessments of pain intensity are indicated to be lower than those of patients. ${ }^{[0]}$

Approaches to ensure the patient's right to life and to pain relief which are one of the purposes of medicine should be accomplished in compliance with ethical principles. ${ }^{[10,11]}$ Among these approaches are to inform the patient about the disease, to obtain his/her informed consent, to protect his/her privacy, to ensure humane care and treatment, to protect the right of a patient to die with dignity and in a painless way especially for terminally ill cancer patients, to minimize the unwanted effects of analgesic treatment, to administer appropriate medicine appropriately, to determine the pros and cons of the treatment, and to concern for pain. In terms of human rights and ethical rules, not relieving pain is a crime and thus it is considered as a bad approach. ${ }^{[10,12]}$

In fact, pain must be managed with the best method or at least minimized to the limits within which the patient feels comfortable. Within the context of nonmal eficence, not allowing a patient to suffer pain by limiting the administration of pain relievers for fear that they may cause death is advocated by the double effect doctrine. The main purpose of the ad- ministration of pain medication needed by patients to relieve intolerable suffering despite the possibility of death is to provide peace and comfort for the patient. Therefore, since death is the unintended consequence of this action, necessary measures should be taken. ${ }^{[10,13,14]}$ In a study conducted with medical students, the majority of the students did not agree with the view that "a patient with severe pain who is expected to die soon should be administered an overdose of pain medication".[15] In Balseven Odabaşı and Örnek Büken's (2009) study, while $29 \%$ of the patients agreed with the administration of an overdose of pain medication to the patient, only $8 \%$ of the physicians approved the practice. ${ }^{[16]}$ In the context of an European collaborative research project Miccinesi et al. ${ }^{[17]}$ (2005) carried out a study in six countries and determined that while the majority of the physicians agreed with the view that the decision to administer pain medications likely to cause the patient's death should be made by the physician and the patient together, more than half of the physicians refused to administer lethal doses of drugs to terminally-ill patients with severe pain who were unable to make decisions.

When approaches to pain relief are implemented, the patient's opinion, participation and values regarding the issue are of importance. Pain management has been subject to prejudices, culture, misbeliefs, ignorance of the pain expressed by the patient, and improper ethical principles for many years. ${ }^{[18,19]}$ However, it is necessary to be aware of moral responsibility which provides an inter-disciplinary approach to pain management and appropriate pain care. In the literature, during the decision-making process to alleviate pain, autonomy, beneficence and do-no-harm principle are focused on. ${ }^{[20]}$ Before making decisions on behalf of patients about ethical approaches, their opinions should first be determined and then provide guidance for health professionals. Although there are a very limited number of studies on this issue, ${ }^{[16]}$ there are many studies on health professionals' attitudes towards the administration of pain medication to terminally-ill patients suffering severe pain..$^{[15,16,21-23]}$ Therefore, our study was aimed at determining the views of the patients admitted to the algology clinic about ethical issues related to pain. 


\section{Materials and Methods}

\section{Population and sample}

Of the patients hospitalized in the algology clinic of a university hospital in the city center of Sivas province, those who were over 18 years old, and volunteered to participate in the study comprised the population of this descriptive study. The study was conducted between June 2010 and December 2010. In the power analysis, the following values were employed: alpha 0.01 , beta 0.10 , and $1-\beta=0.90$. Then the power of the test was found to be $p=0.9021$ and it was decided to include 135 individuals in the study.

\section{Data collection tools}

Data were collected with the Personal Information Form, Visual Analogue Scale (VAS) and the questionnaire including ethical issues related to pain.

Personal Information Form: The form consists of 22 questions on patients' socio-demographic characteristics, their characteristics related to pain and their level of coping with pain, and information related to their disease.

The Visual Analogue Scale (VAS): The scale used for the assessment of pain intensity was developed by Price et al. The scale has a $10 \mathrm{~cm}$-long horizontal line, and the scale's scoring ranges from $0=$ no pain to $10=$ worst pain. The individual is asked to mark the point on the line corresponding to the pain intensity felt by him/her. The distance between the lowest end of the line and the point marked by the individual is measured in centimeters and the numerical value determined indicates the severity of the pain. ${ }^{[24]}$

The Questionnaire Including Ethical Issues Related to Pain: The Likert-style questionnaire developed by the researchers through a literature review includes 15 propositions about pain management approaches to be evaluated by the participants". The Likert-style questionnaire includes 15 propositions about pain management approaches to be evaluated by the participants. ${ }^{[1,19,22,25-28]}$ The participants are asked to respond to the propositions as "I agree", "I disagree" and "I have no idea".

\section{Process}

The data collection tools were completed by the researchers through face-to-face interviews made with those who agreed to participate in the study. It took approximately 10-15 minutes to fill out the forms.

\section{Ethical principles of the study}

Before the study was initiated, approvals were obtained from University Hospital Health Services Research Ethics Committee (Decision no: 2010-03/18) and from the hospital where the study was to be conducted. The purpose of the study was explained to the study population by the researchers and then informed consents of the individuals who agreed to participate in the survey were obtained. The study was conducted in compliance with the Helsinki Declaration.

\section{Statistical evaluation}

The data were analyzed using the SPSS 22.00 package program. To analyze the data, the percentage distribution and analysis of variance (when parametric assumptions came true) were used. To determine what caused the difference, the Tukey test used. The statistical significance level was set at $p<0.05$.

\section{Results}

\section{Descriptive characteristics}

The mean age of the patients was $46.85 \pm 12.92$ (min$\max =20-78)$. Of the patients participating in this study, $49.6 \%$ were between the ages of 35 and 54, $59.3 \%$ were female, $48.9 \%$ were primary school graduates, $58.5 \%$ were unemployed, $82.2 \%$ were married, $80 \%$ resided in the city center, $54.1 \%$ had an income equal to or more than expenses, $79.3 \%$ were hospitalized one to seven days, $41.5 \%$ perceived their health status as moderate, $73.3 \%$ did not have an attendant, $52.6 \%$ were previously hospitalized (Table 1 ).

\section{Pain-related characteristics}

Of the participants, $63 \%$ did not receive pain treatment previously, $37.8 \%$ defined the intensity and frequency pain as "at different intensities but constant", $68.1 \%$ did something to deal with the pain, $65.2 \%$ suffered from pain between 0 and 5 years, $45.9 \%$ took pain medication, and $64.4 \%$ suffered low back pain. The participants' mean VAS score was $6.24 \pm 2.38$ (min-max=0-10) (Table 2). 
Table 1. Descriptive characteristics of the patients $(n=135)$

\begin{tabular}{|c|c|c|}
\hline Descriptive characteristics & $\mathbf{n}$ & $\%$ \\
\hline \multicolumn{3}{|l|}{ Age } \\
\hline 20-34 & 26 & 19.3 \\
\hline $35-54$ & 67 & 49.6 \\
\hline$\geq 55$ & 42 & 31.1 \\
\hline \multicolumn{3}{|l|}{ Gender } \\
\hline Female & 80 & 59.3 \\
\hline Male & 55 & 40.7 \\
\hline \multicolumn{3}{|l|}{ Education level } \\
\hline Literate-illiterate & 12 & 8.9 \\
\hline Primary school & 66 & 48.9 \\
\hline High school & 36 & 26.7 \\
\hline University & 21 & 15.5 \\
\hline \multicolumn{3}{|l|}{ Employment status } \\
\hline Unemployed & 79 & 58.5 \\
\hline Employed & 56 & 41.5 \\
\hline \multicolumn{3}{|l|}{ Marital status } \\
\hline Married & 111 & 82.2 \\
\hline Single & 24 & 17.8 \\
\hline \multicolumn{3}{|l|}{ Place of residence } \\
\hline Village / small town & 9 & 6.7 \\
\hline Town & 18 & 13.3 \\
\hline City & 108 & 80.0 \\
\hline \multicolumn{3}{|l|}{ Income-expenses status } \\
\hline $\begin{array}{l}\text { Income equal to or more } \\
\text { than expenses }\end{array}$ & 73 & 54.1 \\
\hline Income less than expenses & 62 & 45.9 \\
\hline \multicolumn{3}{|l|}{ Duration of hospitalization } \\
\hline 1-7 days & 107 & 79.3 \\
\hline$>7$ days & 28 & 20.7 \\
\hline \multicolumn{3}{|l|}{ Perception of health status } \\
\hline Good & 54 & 40.0 \\
\hline Moderate & 56 & 41.5 \\
\hline Bad & 25 & 18.5 \\
\hline \multicolumn{3}{|l|}{ Having an attendant } \\
\hline Yes & 36 & 26.7 \\
\hline No & 99 & 73.3 \\
\hline \multicolumn{3}{|l|}{ Previously hospitalized } \\
\hline Yes & 71 & 52.6 \\
\hline No & 64 & 47.4 \\
\hline
\end{tabular}

\section{Views about ethical issues related to pain}

The patients believed that they had the right to pain relief $(92.6 \%)$, that it was the health professionals' responsibility to provide adequate pain medication $(88.2 \%)$, that they must be informed about all the
Table 2. The patients' pain-related characteristics $(n=135)$

\begin{tabular}{|c|c|c|}
\hline Pain-related characteristics & $\mathbf{n}$ & $\%$ \\
\hline \multicolumn{3}{|l|}{ Receiving pain treatment previously } \\
\hline Yes & 50 & 37.0 \\
\hline No & 85 & 63.0 \\
\hline \multicolumn{3}{|l|}{ Intensity and frequency of pain } \\
\hline At the same intensity and constant & 35 & 25.9 \\
\hline At different intensities and constant & t 51 & 37.8 \\
\hline Repetitive and regular & 19 & 14.1 \\
\hline Persistent and occurs at intervals & 30 & 22.2 \\
\hline \multicolumn{3}{|l|}{ Attempts to relive pain } \\
\hline Yes & 92 & 68.1 \\
\hline No & 43 & 31.9 \\
\hline \multicolumn{3}{|l|}{ Methods to deal with pain* } \\
\hline Medication & 62 & 45.9 \\
\hline $\begin{array}{l}\text { Others (porous plaster, massage, } \\
\text { exercise, heat therapy, resting, } \\
\text { listening to music) }\end{array}$ & 54 & 39.8 \\
\hline \multicolumn{3}{|l|}{ The duration of pain } \\
\hline Unknown & 15 & 11.1 \\
\hline $0-5$ years & 88 & 65.2 \\
\hline $6-10$ years & 20 & 14.8 \\
\hline$\geq 11$ years & 12 & 8.9 \\
\hline \multicolumn{3}{|l|}{ The location of pain* } \\
\hline Head and neck & 61 & 45.2 \\
\hline Shoulder and back & 26 & 19.3 \\
\hline Lower back & 87 & 64.4 \\
\hline \multirow[t]{2}{*}{ Limbs } & 47 & 34.8 \\
\hline & Min-Max & $\mathbf{X} \pm \mathbf{S}$ \\
\hline VAS & $0-10$ & $6.24 \pm 2.38$ \\
\hline
\end{tabular}

*Multiple answers were given.

interventions they were to undergo (91.1\%), and that if the information was of no benefit to the patient, the patient should not be given any information by the physician after receiving the consent of the family (50.4\%). While $88.9 \%$ of the respondents stated that health professionals should inform them about the routine treatment procedures before, during and after any intervention was carried out, $84.4 \%$ of tem said that they had the right to refuse the treatment. The patients also stated that their private information should be kept in secret $(86.6 \%)$, that they had the right to see patient file and to receive a copy of it $(91.1 \%)$, that their cultural values should be respected $(90.4 \%)$, that they 
must be clearly informed of the expected level of pain relief, and the highest amount, possible side effects and costs of medication to be administered (88.1\%), and that their $(94.8 \%)$ or family's (55.6\%) opinion should be obtained when a decision is made about them.

While $43.0 \%$ of the patients did not agree with the proposition "When a terminal-stage cancer patient with unrelievable pain requests for overdoses of pain medication possibly to cause death, the physi- cian must prescribe it", 35.5\% of them agreed with it. While the proposition "When a terminal-stage cancer patient with unrelievable pain and his/her family request for overdoses of pain medication possibly to cause death, the physician must prescribe it" was not agreed by $51.9 \%$ of the participants, the proposition "When a terminal-stage cancer patient with unrelievable pain requests for overdoses of pain medication possibly to cause death even though his/her family refuses, the physician must prescribe it" was not agreed by $44.4 \%$ of them (Table 3 ).

Table 3. The patients' views about ethical issues related to pain

\begin{tabular}{|c|c|c|c|c|c|c|}
\hline \multirow[t]{2}{*}{ Ethical Issues } & \multicolumn{2}{|c|}{ I agree } & \multicolumn{2}{|c|}{ I disagree } & \multicolumn{2}{|c|}{ I have no idea } \\
\hline & $\mathbf{n}$ & $\%$ & $\mathbf{n}$ & $\%$ & $\mathbf{n}$ & $\%$ \\
\hline I have the right to pain relief when I have pain. & 125 & 92.6 & 2 & 1.5 & 8 & 5.9 \\
\hline $\begin{array}{l}\text { I believe that it is the responsibility of health } \\
\text { professionals to provide me with adequate pain } \\
\text { medication when I have pain. }\end{array}$ & 119 & 88.2 & 6 & 4.4 & 10 & 7.4 \\
\hline $\begin{array}{l}\text { I have the right to exactly know the characteristics, } \\
\text { risks and benefits of, and if any, alternatives to the } \\
\text { interventions to be performed on me. }\end{array}$ & 123 & 91.1 & 3 & 2.2 & 9 & 6.7 \\
\hline $\begin{array}{l}\text { If the physician thinks that it would be better not to } \\
\text { inform me, he may not inform me after receiving the } \\
\text { consent of my family. }\end{array}$ & 68 & 50.4 & 50 & 37.0 & 17 & 12.6 \\
\hline $\begin{array}{l}\text { Health professionals should inform me about the } \\
\text { routine treatment procedures before, during and after } \\
\text { any intervention was carried out. }\end{array}$ & 120 & 88.9 & 4 & 3.0 & 11 & 8.1 \\
\hline $\begin{array}{l}\text { I have the right to refuse or stop the treatment or } \\
\text { intervention. }\end{array}$ & 114 & 84.4 & 5 & 3.7 & 16 & 11.9 \\
\hline $\begin{array}{l}\text { All the private information about me should be kept } \\
\text { in secret after treatment. }\end{array}$ & 117 & 86.6 & 2 & 1.5 & 16 & 11.9 \\
\hline $\begin{array}{l}\text { I have the right to see my patient file and to receive } \\
\text { a copy of it. }\end{array}$ & 123 & 91.1 & 1 & 0.8 & 11 & 8.1 \\
\hline $\begin{array}{l}\text { When a decision is made about me, my family should } \\
\text { be consulted too. }\end{array}$ & 75 & 55.6 & 43 & 31.8 & 17 & 12.6 \\
\hline $\begin{array}{l}\text { When a terminal-stage cancer patient with unrelievable } \\
\text { pain requests for overdoses of pain medication possibly } \\
\text { to cause death, the physician must prescribe it. }\end{array}$ & 48 & 35.5 & 58 & 43.0 & 29 & 21.5 \\
\hline $\begin{array}{l}\text { When a terminal-stage cancer patient with unrelievable } \\
\text { pain and his/her family request for overdoses of pain } \\
\text { medication possibly to cause death, the physician must } \\
\text { prescribe it. }\end{array}$ & 34 & 25.1 & 70 & 51.9 & 31 & 23.0 \\
\hline $\begin{array}{l}\text { When a terminal-stage cancer patient with unrelievable } \\
\text { pain requests for overdoses of pain medication possibly } \\
\text { to cause death even though his/her family refuses, the } \\
\text { physician must prescribe it }\end{array}$ & 32 & 23.7 & 60 & 44.4 & 43 & 31.9 \\
\hline
\end{tabular}


The patients' mean VAS scores in terms of their views about ethical issues related to pain

Statistically significant differences were found between the mean VAS scores and the propositions "When a terminal-stage cancer patient with unrelievable pain requests for overdoses of pain medication possibly to cause death, the physician must prescribe it" and "When a terminal-stage cancer patient with unrelievable pain and his/her family request for overdoses of pain medication possibly to cause death, the physician must prescribe it" $[(p=0.000)(p=0.014)$ respectively]. Those who disagreed with these propositions had higher mean VAS scores (Table 4).

\section{Discussion}

The findings of this study conducted to determine the views of the patients hospitalized in the algology clinic about ethical issues related to pain are discussed below. The majority of the participants had lower back, head and neck pain. Neither were they terminal-stage patients, nor did they have unbearable pains. They had pain at a moderate level.

Almost all the patients believed that they had the right to pain relief, and that health care professionals were primarily responsible for providing pain relief. Keeping pain that can be controlled within the limits that the patient feels comfortable is the patient right, due to respect for human right..$^{[12,29-31]}$ In this context, one of the important responsibilities of health professionals is to provide adequate analgesia to the person suffering pain. ${ }^{[31]}$ In accordance with the ethical principle of beneficience, health care workers have a responsibility to relieve patients' pain, which was determined by national and international ethical codes. The ethical framework for the management of pain includes the following: supporting pain management as a statutory right, providing legislation and assurance regarding pain management abuse, elder abuse and professional misconduct, determining failures of pain management, defining pain management as a fundamental human right, and determining and implementing rules and standards of pain management by professional organizations.

Failure to relieve pain is considered as poor practices of medicine, violation of a fundamental human right and professional misconduct. The World Health Organization (WHO) suggests that opioid analgesics used for pain management should be easily accessed/ available, and that guidelines of national programs associated with palliative care and pain should be introduced and distributed. ${ }^{[26]}$ Shift to patient-centered approaches in medicine reflects on good practices of health care professionals in pain management. ${ }^{[18]}$ Ethical and legal principles' supporting each other in pain

Table 4. The patients' mean visual analogue scale scores in terms of their views about ethical issues related to pain

\begin{tabular}{|c|c|c|c|c|}
\hline & \multicolumn{4}{|c|}{$\begin{array}{l}\text { When a terminal-stage cancer patient with unrelievable pain requests for overdoses of pain } \\
\text { medication possibly to cause death, the physician must prescribe it. }\end{array}$} \\
\hline & I agree & I disagree & I have no idea & $\mathbf{F}, \mathbf{p}$ \\
\hline & $(n=48)$ & $(n=58)$ & $(n=29)$ & \\
\hline & $\mathrm{X} \pm \mathrm{SD}$ & $\mathrm{X} \pm \mathrm{SD}$ & $\mathrm{X} \pm \mathrm{SD}$ & \\
\hline \multirow[t]{6}{*}{ VAS } & $5.35 \pm 2.29$ & $7.17 \pm 2.23$ & $5.86 \pm 2.24$ & ${ }^{* *} \mathrm{~F}=9.049$ \\
\hline & & & & $\mathrm{p}=0.000^{*}$ \\
\hline & $\begin{array}{l}\text { When a terminal-st } \\
\text { medication possibl } \\
\text { prescribe it. }\end{array}$ & $\begin{array}{l}\text { atient with } \\
\text { ath even th }\end{array}$ & $\begin{array}{l}\text { le pain requests } \\
\text { er family refuse. }\end{array}$ & $\begin{array}{l}\text { oses of pain } \\
\text { sician must }\end{array}$ \\
\hline & I agree & I disagree & I have no idea & $F, p$ \\
\hline & $(n=32)$ & $(n=60)$ & $(n=43)$ & \\
\hline & $\mathrm{X} \pm \mathrm{SD}$ & $\mathrm{X} \pm \mathrm{SD}$ & $\mathrm{X} \pm \mathrm{SD}$ & \\
\hline \multirow[t]{2}{*}{ VAS } & $5.56 \pm 2.51$ & $6.90 \pm 2.23$ & $5.83 \pm 2.31$ & ${ }^{* *} \mathrm{~F}=4.399$ \\
\hline & & & & $p=0.014^{*}$ \\
\hline
\end{tabular}

${ }^{*} \mathrm{p}<0.05 ;{ }^{*}$ One-way variance analysis (Anova); VAS: visual analogue scale. 
management is thought to be more helpful to health care professionals in pain control. ${ }^{[26,30]}$

Almost all of the patients believed that they had the right to exactly know the characteristics, risks and benefits of, and if any, alternatives to the interventions to be performed on them. While half of the participants stated that the patient should not to be informed by the physician after receiving the family's consent if the information was of no benefit to the patient, the great majority of said that they had the right to refuse the treatment or intervention. That patients should be informed of all the applications related to pain and that their informed consent should be obtained is under the protection of the code of ethics, law and patients' rights to ensure their autonomy. ${ }^{[25,32]}$

This information can be given either to the patient himself, or to the surrogate at the request of the patient. ${ }^{[25,31,32]}$ After being informed, a patient has the right to refuse or stop intervention he/she undergoes. In such a case, the patient should also be told about the possible consequences if the intervention is not performed ${ }^{[31]}$ because the patient's awareness and perception related to the treatment, quality of life, technical opportunities and the prognosis of the disease may not be adequate. In these cases, the patient may need more descriptive information. ${ }^{[25,33]}$

Analysis of the participants' other requests regarding their being informed revealed that the majority of them agreed that their private (personal) information should be kept in secret (appropriately) after the treatment was over, that they had the right to see patient file and to receive a copy of it, that their cultural values should be respected during the diagnosis and treatment, and that the expected level of pain relief, and the highest amount, possible side effects and costs of medication to be administered should be clearly defined when the treatment options are offered to them. When these requests are evaluated in the context of patients' rights in our country, they can be considered as a right in accord with human dignity. ${ }^{[1,32]}$ Ignoring the complaints of a pain patient or refusing his/her reasonable request to pain relief is contrary to the patient autonomy, his/her making conscious decisions regarding his/her care and his/her determining what kind of medical care he/she is to undergo. ${ }^{[20]}$ It is the duty of health care professionals to display appropriate approaches to relieve patients' pain, listen to their pain-related complaints empathetically and respect the patient's autonomy. ${ }^{[26,27]}$ The patient-centered approach with its individualized treatment targets is preferred in pain approach. ${ }^{[34,35]}$ In a study conducted on the issue, it was found that the success of pain management is directly related with health care professionals' making action plans in line with the data obtained from patients and how quickly they intervene in patients' pain and suffering. ${ }^{[36]}$ On the other hand, in another study, it was determined that patients were not able to tell nurses their requests because nurses were short of time. ${ }^{[35]}$ Understanding of pain and fulfilling the responsibility to respond to pain are not so easy. Pain has devastating effects on people who suffer pain, and family and health care workers who witness the pain. ${ }^{[27]}$ Unrelieved pain-related problems and suffering are referred to as major ethical concerns for health professionals in different clinical settings. ${ }^{[37]}$ In a study carried out by video recording of patient-physician communication and using patients' views, it was found that as the severity of pain increased so did tension experienced in the doctor-patient relationship. ${ }^{[38]}$ Almost all the patients claimed that their opinions should be asked when a decision was made about them, and more than half of them wanted their families to be consulted if this was not possible. Making a decision by taking patient autonomy and the patient's benefit into account is an ethical principle. ${ }^{[19,35,39]}$ Decisions involving pain management should be made carefully and clearly. ${ }^{[27]}$ In the literature, it is stated that health workers' attitudes, perceptions and previous experiences play a more important role in pain management decisions, ${ }^{[19,26]}$ and that neither the patient nor the family (when the patient is unable to make decisions) have a voice in the decision-making process. ${ }^{[25,29]}$ In another study, it was observed that pain management was adversely affected by health professionals' negative attitudes towards cancer pain, beliefs that pain medications do more harm than good and concerns that pain medications may lead to addiction. ${ }^{[40]}$ In Bağtatlı Aydın and Eser's (2010) study, it was found that oncology nurses' assessment of pain was lower than was that of patients. ${ }^{[41]}$ In another study, it was found that while physicians and nurses administered less pain relievers due to 
their fears and worries related to the adverse effects of pain medication the patient's family had higher expectations in pain management. ${ }^{[4]}$ Health professionals may sometimes ignore the intrinsic subjectivity of pain or do not believe that persistent pain may not be unresponsive to standard medications. ${ }^{[19]}$ In their study of 52 nurses, 312 patients and 316 pain experiences, Manias, Botti and Bucknall (2006) observed that patients' participation in pain management decisions was very low. ${ }^{[42]}$ When patients participate in decision-making processes, they feel happier, better and more secure. ${ }^{[19]}$

Limited medical resources pose an obstacle to pain management and may lead to health inequalities. [26,27] Responsibility in pain management includes not only the principle of beneficence and encouragement of good care but also the principle of nonmaleficence. ${ }^{[26]}$ With advancing technology, while health professionals try to do their best in pain management they also face with potentially harmful situations brought about by technology, which leads to the emergence of ethical dilemmas. ${ }^{[27]}$

Almost half of the patients were determined to disagree with the proposition "When a terminal-stage cancer patient with unrelievable pain requests for overdoses of pain medication possibly to cause death, the physician must prescribe it." It was also found that more than half of the participants disagreed with the proposition "When a terminal-stage cancer patient with unrelievable pain and his/her family request for overdoses of pain medication possibly to cause death, the physician must prescribe it", and that nearly half of them did not agree with the proposition "When a terminal-stage cancer patient with unrelievable pain requests for overdoses of pain medication possibly to cause death even though his/her family refuses, the physician must prescribe it". Comparison of the mean VAS scores with the propositions "When a terminal-stage cancer patient with unrelievable pain requests for overdoses of pain medication possibly to cause death, the physician should prescribe it" and "When a terminalstage cancer patient with unrelievable pain and his/ her family request for overdoses of pain medication possibly to cause death, the physician must prescribe it" revealed a statistically significant difference $[(p=0.000)(p=0.014)$ respectively].
Thus, it can be said that patients refused the administration of pain medication likely to cause deaths even if they had severe pain, which may be due to the fact that the majority of the participants of the study had lower back, head and neck pains which were different from unbearable pains of terminal stage.

Administration of overdose medication likely to cause the patient's death is an controversial issue among health care workers too. ${ }^{[15-17,21]}$ Not administering pain medication due to concerns that the patient may die and the patient's suffering pain is unacceptable in terms of ethics.

One of the reasons for this is the double effect doctrine in ethics. In a study of ethics educators, one-third of the educators thought that opioid use would lead to respiratory depression, their opinion related to effects of pain killers was not affected by the double effect doctrine, and approximately $70 \%$ of them assumed that it was related to end-of-life healthcare. Only $15 \%$ of the ethics educators believed that the principle of double effect would discourage clinicians from using opioids to treat pain. ${ }^{[14]}$ According to the results of a study investigating patients' perspectives and experiences of pain management, patients believed that painkillers might lead to addiction and were worried about the side effects of painkillers. This attitude might be due to the negative impression regarding the use of narcotics and other analgesics. ${ }^{[35,43]}$

According to the results of Balseven Odabaşı and Örnek Büken's study (2009) which supports our study findings about the drug overdose, both the physicians and patients agreed that the physician should not prescribe overdose of pain medication which might lead to death, and the comparison of responses given by the physicians and patients in the same study revealed that the physicians agreed to this view more than did the patients. ${ }^{[16]}$ In another study of medical students which compared the students' views before and after the education, the students objected to physicians' prescribing pain medication to terminal-stage patients with excruciating pain after the education. ${ }^{[21]}$

\section{Conclusion}

In the present study, the patients wanted that they should be informed and tasked about their opinions 
about the interventions they were to undergo, that their private information should be kept in secret, that their cultural values should be respected, and that they and their families should be included in decision-making process about the treatment options; however, they did not want to be administered overdose of medication possibly to cause death. Health care professionals should ensure that patients' informed consents were obtained, and help patients to access the true data about them and to use their right to pain relief. It is recommended that training programs should be organized for health care professionals so that they can deliver quality health care to ensure patient satisfaction, that implementation of evidence-based interventions should be supported, that chronic pain awareness should be raised in order to prevent discrimination and stigmatization, and that multimodal therapies and public policies regarding pain management should be developed. It is also recommended that similar studies should be conducted with terminal-stage patients with severe pain to make comparisons.

\section{Limitations of the study}

The results of this study can only be applied to the study sample; it cannot be generalized. Another limitation of the study, the respondents' answers to questions in the questionnaire which was used to obtain the patients' opinion on ethical issues were not adequate to make statistical comparisons.

\section{Conflict-of-interest issues regarding the authorship or article: None declared.}

\section{Peer-rewiew: Externally peer-reviewed.}

\section{References}

1. Pirbudak Çöçelli L, Bacaksız BD, Ovayolu N. The nurse factor in pain therapy. Gaziantep Med Journal 2008;14(1):538.

2. Kuzeyli Yildirim Y, Uyar M, Fadillioğlu C. [Cancer pain and its influence on quality of life]. [Article in Turkish]. Agri 2005;17(4):17-22.

3. Reinisch $\mathrm{C}$. Challenging case of chronic pain in the emergency department medical and ethical issues of management. Advanced Emergency Nursing Journal 2007;29(1):35-40. [CrossRef]

4. Hickman SE, Tolle SW, Tilden VP. Physicians' and nurses' perspectives on increased family reports of pain in dying hospitalized patients. J Palliat Med 2000;3(4):413-8. [CrossRef]

5. Kuru T, Yeldan I, Zengin A, Kostanoğlu A, Tekeoğlu A, AkbabaYA, et al. [The prevalence of pain and different pain treat- ments in adults]. [Article in Turkish]. Agri 2011;23(1):22-7.

6. Breivik H, Collett B, Ventafridda V, Cohen R, Gallacher D. Survey of chronic pain in Europe: prevalence, impact on daily life, and treatment. Eur J Pain 2006;10(4):287-333.

7. Eti Aslan F. The assessment methods of pain. Journal of Cumhuriyet University School of Nursing 2002;6(1):9-16.

8. Berk HO, Bahadir G. [The experience of chronic pain and pain beliefs]. [Article in Turkish]. Agri 2007;19(4):5-15.

9. Sungurtekin H. Analgesia in intensive care. J Turk Soc Intens Care 2006;4(1):58-64.

10. Ersoy N. Ethics in oncology nursing. Turkish Journal of Oncology 2009;24(4):191-7.

11. Edwards I, Jones M, Thacker M, Swisher LL. The moral experience of the patient with chronic pain: bridging the gap between first and third person ethics. Pain Med 2014;15(3):364-78. [CrossRef]

12. Ağrı Ve Etik - Tıp Ahlakı. Available at: http://e-kutuphane. teb.org.tr/pdf/raporlar/agri_analj/13.pdf. Accessed at July 9, 2019.

13. Türk Tabipleri Birliği Etik Kurulu. Türk Tabipleri Birliği Etik Bildirgeleri. Available at: https://www.ttb.org.tr/kutuphane/etik_bldgeler2010.pdf. Accessed at July 9, 2019.

14. Macauley $R$. The role of the principle of double effect in ethics education at US medical schools and its potential impact on pain management at the end of life. J Med Ethics 2012;38(3):174-8. [CrossRef]

15. Yıldırım G, Aksu M. Opinion of medical students about the end of life. Cumhuriyet Med J 2010;32(2):140-8.

16. Balseven Odabaşı A, Örnek Büken N. Informed consent and ethical decision making in the end of life: Hacettepe example. Turkey Clinics J Med Sci 2009;29(5):1041-54.

17. Miccinesi G, Fischer S, Paci E, Onwuteaka-Philipsen BD, Cartwright $C$, van der Heide $A$, et al. Physicians' attitudes towards end-of-life decisions: a comparison between seven countries. Soc Sci Med 2005;60(9):1961-74. [CrossRef]

18. Daher M. Pain relief is a human right. Asian Pac J Cancer Prev 2010;11(suppl 1):97-101.

19. Bernhofer E. Ethics and pain management in hospitalized patients. OJIN: The Online Journal of Issues in Nursing 2011; 17: (1) Available at: http://ojin.nursingworld.org/ MainMenuCategories/ANAMarketplace/ANAPeriodicals/ OJIN/TableofContents/Vol-17-2012/No1-Jan-2012/Ethicsand-Pain-Management.html. Accessed June 17,2019.

20. Post LF, Blustein J, Gordon E, Dubler NN. Pain: ethics, culture, and informed consent to relief. J Law Med Ethics 1996 Winter;24(4):348-59. [CrossRef]

21. Yıldırım G, Aksu M, Ertekin Pınar Ş. Effects of end of liferelated ethics training given in the process of clinical training on medical students' attitudes towards end of life. Tıp Eğitimi Dünyası J 2014;13(40):5-18. [CrossRef]

22. Ruhnke GW, Wilson SR, Akamatsu T, Kinoue T, Takashima Y, Goldstein MK, et al. Ethical decision making and patient autonomy: a comparison of physicians and patients in Japan and the United States. Chest 2000;118(4):1172-82.

23. Buken NO, Balseven-Odabasi A. Physicians' attitudes at the end-of-life: a cross-cultural evaluation. Med Law 
2013;32(4):549-65.

24. Price DD, McGrath PA, Rafii A, Buckingham B. The validation of visual analogue scales as ratio scale measures for chronic and experimental pain. Pain 1983;17(1):45-56.

25. Öner Erkekol F, Numanoğlu N, Ural Gürkan Ö, Kaya A. Ethical issues related to intensive care. Turkish Thoracic Journal 2002;3(3):307-16.

26. Brennan F, Carr DB, Cousins M. Pain management: a fundamental human right. Anesth Analg 2007;105(1):205-21.

27. Ferrell B. Ethical perspectives on pain and suffering. Pain Manag Nurs 2005;6(3):83-90. [CrossRef]

28. Johnson SH. Legal and ethical perspectives on pain management. Anesth Analg 2007;105(1):5-7. [CrossRef]

29. Kılıç M, Öztunç G. Methods used in pain control and the role of the nurse. Firat Journal of Health Services 2012;7(21):35-51.

30. Hall JK, Boswell MV. Ethics, law, and pain management as a patient right. Pain Physician 2009;12(3):499-506.

31. Düzel V. Nurses and patients postopertaive pain assessment comparision. Çukurova University Institute of Health Sciences Department of Nursing. [Master Thesis]. Adana, 2008.

32. Hasta Hakları Yönetmeliği. Available at: http://www.mevzuat.gov.tr/Metin.Aspx?MevzuatKod=7.5.4847\&Mevzuat Iliski=0\&sourceXmlSearch=hasta\%20haklar\%C4\%B1. Accessed at July 9, 2019.

33. Schnakers C, Zasler ND. Pain assessment and management in disorders of consciousness. Curr Opin Neurol 2007;20(6):620-6. [CrossRef]

34. O'Brien EM, Staud RM, Hassinger AD, McCulloch RC, Craggs JG, Atchison JW, et al. Patient-centered perspec- tive on treatment outcomes in chronic pain. Pain Med 2010;11(1):6-15. [CrossRef]

35. Rejeh N, Vaismoradi M. Perspectives and experiences of elective surgery patients regarding painmanagement. Nurs Health Sci 2010;12(1):67-73. [CrossRef]

36. Beck SL, Towsley GL, Berry PH, Lindau K, Field RB, Jensen $S$. Core aspects of satisfaction with pain management: cancer patients' perspectives. J Pain Symptom Manage 2010;39(1):100-15. [CrossRef]

37. Van Niekerk LM, Martin F. The impact of the nurse-physician professional relationship on nurses' experience of ethical dilemmas in effective pain management. J Prof Nurs 2002;18(5):276-88. [CrossRef]

38. Henry SG, Eggly S. The effect of discussing pain on patientphysician communication in a low-income, black, primary care patient population. J Pain 2013;14(7):759-66. [CrossRef]

39. Beauchamps TL, Childress JF. Principles of biomedical ethics. 4. Edition. New York: Oxford University Press, 1994.

40. Al Khalaileh M, Al Qadire M. Barriers to cancer pain management: Jordanian nurses' perspectives. Int J Palliat Nurs 2012;18(11):535-40. [CrossRef]

41. Bağtatlı Aydın H, Eşer İ. Comparison of the pain assessment of the nurses and cancer patients. Journal of Ege University School of Nursing 2010;26(1):11-23.

42. Manias E, Botti M, Bucknall T. Patients' decision-making strategies for managing postoperative pain. J Pain 2006;7(6):428-37. [CrossRef]

43. Bédard D, Purden MA, Sauvé-Larose N, Certosini C, Schein $C$. The pain experience of post surgical patients following the implementation of an evidence-based approach. Pain Manag Nurs 2006;7(3):80-92. [CrossRef] 